УДК 373.2:316.344 (045)

(C) Апрєлєва I. В., 2021

https://orcid.org/0000-0002-3012-7630

DOI 10.34142/23128046.2021.51.01

I. В. Апрелєва

\title{
СОЦАЛЬНО-ПЕДАГОГІЧНЕ ПАРТНЕРСТВО В ОСВІТІ - СУТНІСТЬ, ОСНОВНІ ІДЕЇ
}

У статті висвітлено особливості соиіально-педагогічного партнерства в освіті, його основні орієнтири. Зроблено акиент на тому, що у вітчизняній педагогічі соиіально-педагогічне партнерство необхідно розглядати як діалогічне відношення сочіальних суб 'єктів, що забезпечує єдність, гармонізацію соціальних структур та вироблення освітньої стратегії єдиних дій. Це зумовлює інтеграцію інтересів різних соціальних груп у єдиному освітньому та інформачійному полі. Зазначено види (за формою: договірне, організачійне; за етапами: підготовчий, організаційний, функиіональний; за рівнем: макро, мезо, мікро-рівень; за типом взаємодії: благодійність, спонсорство, співробітництво та інвестиціï), форми (партнерство в галузі дошкільної освіти; партнерства ЗДО з представниками інших сфер (макросередовища), а саме: послуг охорони здоров'я, культури, фізичної культури, громадських організацій, фондів, органів управління освітою на рівні району, міста, області, служб сочіального забезпечення сім'ї та дітей, а також соціальні послуги взаємодії з їх батьками (законними представниками); партнерство зі спонсорами, благодійними організаціями), принципи (добровільності, рівноправності сторін, поваги інтересів один одного, дотримання законів та нормативних актів) сочіальнопедагогічного партнерства. Виокремлено основні аспекти процесу реалізаиіі соціально-педагогічного партнерства: розвиток освітнього потенціалу дошкільного закладу; реалізащія та розвиток виховного потенціалу сім'ї, партнерство дошкільного закладу та сім'ї; взаємодія сочіальних інститутів $i$ дошкільного закладу; включення дошкільнят у суспільно значущу діяльність. Визначено проблеми, щз ускладнюють організацію соціально-педагогічного партнерства та запропоновано напрями його подальшого розвитку (підвищення рівня комунікативної компетенції педагогів з взаємодї з батьками для формування сімейних традиџій; підвищення рівня психолого-педагогічних знань батьків; розвиток у педагогів та батьків здатності до позитивного діалогу; використання нових нетрадиційних форми та методів роботи з сім'єю, як чинник підвищення освіти дітей; педагогічна та психологічна освіта сім'ї через інформачійні технологіï).

Ключові слова: освіта, заклад дочкільної освіти, сочіально-педагогічне партнерство, педагог, дитина, сім'я.

Aprielieva I. V. Socio-pedagogical partnership in education - essence, main ideas. The article highlights the features of socio-pedagogical partnership in education, its main guidelines. Emphasis is placed on the fact that in domestic 
pedagogy socio-pedagogical partnership should be considered as a dialogical relationship of social actors, ensuring unity, harmonization of social structures and the development of educational strategy for joint action. This leads to the integration of the interests of different social groups in a single educational and information field. The types (by form: contractual, organizational; by stages: preparatory, organizational, functional; by level: macro, meso, micro-level; by type of interaction: charity, sponsorship, cooperation and investment), forms (partnership in the field of preschool education) are indicated. partnerships of $Z D O$ with representatives of other spheres (macroenvironment), namely health services, culture, physical culture, public organizations, funds, education authorities at the district, city, oblast, social security services for families and children, and also social services of interaction with their parents (legal representatives), partnership with sponsors, charitable organizations), principles (voluntariness, equality of the parties, respect for each other's interests, observance of laws and regulations) of social and pedagogical partnership. The main aspects of the process of realization of social and pedagogical partnership, development of educational potential of preschool institution are singled out; realization and development of the educational potential of the family, partnership of the preschool institution and the family; interaction of social institutions and preschool institution; inclusion of preschoolers in socially significant activities. Problems that complicate the organization of socio-pedagogical partnership are identified and directions for its further development are proposed (increasing the level of communicative competence of teachers in interaction with parents to form family traditions; increasing the level of psychological and pedagogical knowledge of parents; development of teachers 'and parents' ability to positive dialogue; new nontraditional forms and methods of working with the family as a factor in improving the education of children; pedagogical and psychological education of the family through information technology).

Key words: education, preschool education institution, social and pedagogical partnership, teacher, child, family.

Вступ. Внаслідок процесів глобалізації та інтернаціоналізації сучасний світ кардинально змінився. Середовище суспільства стає дедалі більш культурно різноманітним, а виховання громадянина, спроможність жити активним та ефективним життям у ньому є одним із найактуальніших викликів. У результаті заклади освіти, починаючи 3 дошкільних, намагаються нейтралізувати негативний соціальний досвід, розвивати позитивне розуміння та толерантну поведінку, формувати ефективні навички взаємодії. Тому метою виховного процесу має бути не тільки забезпечення знань, а й підготовка всебічно розвиненої, духовно і морально зрілої особистості, готової відповідати на виклики сучасного життя. Цьому має сприяти атмосфера взаємодії всіх учасників такого процесу i включення ціннісних установок у життя особистості. Інноваційною ідеєю, яка містить творчий зміст, ілюструє і відображає модель вищезазначених установок, безумовно, є соціально-педагогічне партнерство 
(СПП). СПП в освіті - це взаємозв'язок педагогів, дітей та батьків у процесі добровільної спільної діяльності на рівно вигідних умовах, яка спрямована на вирішення завдань виховання та навчання, заснована на взаємодії та взаємоповазі. Координуюча роль у побудові системи партнерства відводиться освітній організації. Один із результатів, що підтверджує ефективність взаємодії, - це підвищення рівня батьківської компетентності. У зв'язку з цим заслуговує особливої уваги теоретичне обгрунтування даної ідеї як чинника підвищення якості дошкільної освіти, що визначається орієнтаціями сучасної системи освіти та культури на інтелектуальний та творчий розвиток дітей, з одного боку, та інтеграцію зусиль освітніх соціальних інститутів на розвиток наступності дошкільного і початкового навчання.

Значний науковий інтерес до проблем залучення представників соціальних груп в освітній процес з метою підвищення ефективності цієї взаємодії мають наукові праці Є. Арнаутової, Г. Атаманчука, Ю. Атемаскіна, Є. Волкової, Г. Глушко, Н. Корненко, Н. Лісової, Н. Мішин, Н. Наібуліної, Т. Олійник, Дж. Патнаїк, В. Торохтія, Т. Фуряєвої. Окремі аспекти взаємозв'язку сім'ї та закладу освіти у формуванні особистості дитини висвітлено у роботах Л. Баккен, О. Балалієвої, Н. Браун, В. Бузні, В. Даунінг, Л. Загик, О. Кононко, Т. Кулікової, О. Логвінової, В. Маішевої, Л. Островської, Л. Павлюк, Н. Химич та ін. Беручи до уваги те, що наукових напрацювань за даною темою достатньо, тим не менш багато теоретичних та практичних аспектів залишаються не розробленими, зокрема, це стосується вивчення соціально-педагогічного партнерства як чинника підвищення якості дошкільної освіти.

Мета та завдання. Мета статmі - визначити особливості соціальнопедагогічного партнерства в освіті, а також його проблеми та подальші напрями розвитку.

Методи дослідження. У процесі дослідження нами були використані такі методи, як-от: аналіз, узагальнення, систематизація психологопедагогічних, соціологічних праць учених, енциклопедично довідкової літератури з соціальнопедагогічного партнерства, які дали змогу вивчити та проаналізувати суть поняття «соціально-педагогічне партнерство» та схарактеризувати його зміст, визначити основні його напрями.

Виклад основного матеріалу. Соціально-педагогічне партнерства як методологічно актуальний комплекс взаємопов'язаних понять, принципів, ідей та методів педагогічної діяльності розроблено в рамках школи «Соціальнопедагогічний підхід у професійній діяльності» під керівництвом професора В. Торохтія. Соціально-педагогічне партнерство передбачає здійснення освітнього процесу на основі суспільства та його виховного потенціалу через взаємодію з соціальними інституціями, залучення дітей до соціально значущої 
діяльності та соціальних відносин, соціальної інклюзії. Такий підхід вимагає розвитку суспільних потреб людини та здібностей у процесі навчання (Torokhtyi, 2019; Torokhtyi, 2018).

Поняття «соціально-педагогічне партнерство» (СПП) вивчалося багатьма зарубіжними та вітчизняними фахівцями. Так, важливість соціальнопедагогічного партнерства у формуванні особистості підкреслюють Л. Баккен, Н. Браун та В. Даунінг. Автори зазначають, що трансформація інститутів соціалізації (сім'я, суспільство, освітні організації) призводить до зміни моделей соціальної поведінки людини, яка, у свою чергу, недостатньо зрозуміла i потребує соціально-психологічного, а також соціально-педагогічного осмислення (Bakken, 2017).

На думку вченої Н. Лісової, СПП є видом соціального партнерства та демократичної взаємодії рівноправних суб'єктів, які об’єднані для досягнення спільних цілей, вирішення завдань у всебічному розвитку особистості, іiі ключових навичок (Лісова, 2021).

Науковець О. Балалієва зазначає, що соціально-педагогічне партнерство сприймається як особливий тип взаємодії закладів освіти 3 учасниками освітнього процесу, державними та місцевими органами влади, громадськими організаціями, сім'єю, що націлений на узгодження та реалізацію інтересів учасників цього процесу (Balalyeva, 2012).

Дослідник В. Бузні наголошує на важливості взаємодії «педагог-дитинасім'я», характеризуючи ії як компетентну співучасть. Розвиток партнерських відносин закладу освіти та сім'ї формує у батьків готовність до співробітництва, мотивацію, усвідомлення необхідності подібної взаємодії, їх активність та участь у житті установи (Buzni, 2019).

Не менш важливою $\epsilon$ позиція Т. Олійник, де соціально-педагогічне партнерство розглядається як окрема форма соціальної взаємодії закладу освіти 3 фізичними або юридичними особами та розгортається на засадах визначальної ролі навчального закладу в реалізації його особистісно-розвиваючих функцій. Таке партнерство включає в себе сім'ю, педагогів, адміністрацію навчального закладу (Oliinyk, 2019).

У той же час не можна не погодитися з твердженням Л. Павлюк, згідно якого соціально-педагогічне партнерство - це співпраця для здійснення погодженої діяльності за умови дотримання спільно прийнятих сторонами пріоритетів. Ключова ідея СПП в освіті полягає в тому, що для вирішення проблем у цій соціально значущій сфері необхідні зусилля всього суспільства. У світі широко визнано, що, залишаючись засобом відтворення наявних у конкретних соціумах інститутів і відношень, воно все більше стає основним інструментом забезпечення та перетворень (Pavliuk, 2020). 
Обговорення. Аналіз наукової літератури дає можливість констатувати, що у вітчизняній педагогіці соціально-педагогічне партнерство необхідно розглядати як діалогічне відношення соціальних суб'єктів, що забезпечує єдність, гармонізацію соціальних структур та вироблення освітньої стратегії єдиних дій. Це зумовлює інтеграцію інтересів різних соціальних груп у єдиному освітньому та інформаційному полі.

Зміст соціально-педагогічного партнерства визначається метою та завданнями освітньої установи, суспільства, відділу освіти, стратегією та тактикою розвитку системи дошкільної освіти. Головним завданням освітнього закладу є формування молодого покоління із високим рівнем сформованості людської та громадянської гідності, правовими гарантіями та заслужено наданими духовними та матеріальними благами, яке реально здатне сприйняти, критично оцінити, а головне - впроваджувати та розвивати ідеї демократії та соціальної рівності.

Разом 3 тим, очевидним $є$ те, що система соціально-педагогічного партнерства є рядом відносин. Аналіз джерел показав, що є кілька підходів до його класифікації. Виділяють наступні види (рис. 1):

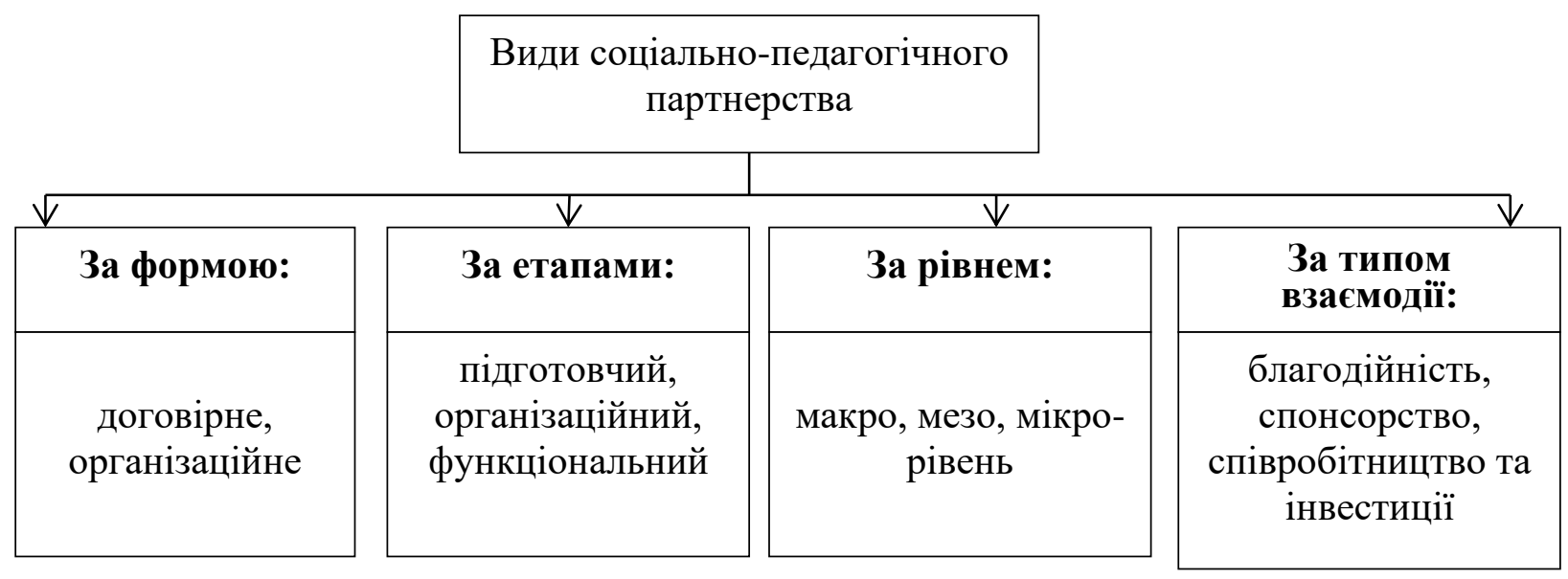

Рис. 1 - Види соціально-педагогічного партнерства

На сьогоднішній день заклад дошкільної освіти (ЗДО) - це єдиний освітній простір, який $\epsilon$ відкритою формою співробітництва, платформою соціальнопедагогічного партнерства. Соціально-педагогічне партнерство ЗДО з іншими зацікавленими сторонами може мати такі форми (Buzny, 2019; Bakken, 2017):

- партнерство в галузі дошкільної освіти. Це партнерство включає: педагогічні консультації дитячих садків, дошкільних фахівців Асоціації 3 актуальних питань допомоги дітям, батькам; батьківське співтовариство; методичне об'єднання педагогів з різних установ - соціальних груп, професійної спільноти; 
- партнерство ЗДО з представниками інших сфер, а саме: послуг охорони здоров’я, культури, фізичної культури, громадських організацій, фондів, органів управління освітою на рівні району, міста, області, служб соціального забезпечення сім'ї та дітей, а також соціальні послуги взаємодії з їх батьками (законними представниками);

- партнерство зі спонсорами, благодійними організаціями (підприємствами, засобами масової інформації, рекламну діяльність дошкільних освітніх організацій) та інші.

Для того, щоб зрозуміти, як повною мірою використовувати потенціал соціального партнерства, керівники ЗДО повинні бути обізнані про місію та цінності конкретної установи, вектор іiі розвитку та можливості залучення потенціалу соціальних партнерів 3 метою їх досягнення. Співробітники ЗДО повинні володіти методами та формами взаємодії з соціальними партнерами, щоб передбачити можливі результати партнерства для розвитку установи, що, у свою чергу, призведе до підвищення якості освітніх послуг (орієнтація позитивного результату спільної діяльності - покращення соціальноособистісного становлення дошкільника).

Важливим $є$ те, що соціально-педагогічна взаємодія з кожним із партнерів здійснюється на основі наступних принципів (Lisova, 2021) :

- добровільності,

- рівноправності сторін,

- поваги інтересів один одного,

- дотримання законів та нормативних актів.

Потенційні партнери (на рівні місцевої громади, регіону чи України) батьки, бізнес-структури, культурно-спортивні установи, шефські підприємства, громадські організації та ін. - визначається ситуативними потребами та місцевими традиціями.

Порівняльний аналіз теорії дошкільної освіти та практики дає можливість представити процес реалізації соціально-педагогічного партнерства в чотирьох аспектах (табл. 1).

Таблиця 1

Основні аспекти прочесу реалізації соціально-педагогічного партнерства в дошкільній освіті

\begin{tabular}{|c|c|}
\hline Аспект & \multicolumn{2}{|c|}{ Опис } \\
\hline 1 & \multicolumn{1}{|c|}{2} \\
\hline 1. Реалізація та & Виховний потенціал тут розглядається як соціально- \\
розвиток виховного & педагогічний феномен, що розкриває комплекс соціальних \\
потенціалу & навколишніх освітніх ресурсів та можливостей, як педагогічна \\
дошкільного закладу & складова кожної особистості, що складається з сукупності його \\
\hline
\end{tabular}




\begin{tabular}{|c|c|}
\hline & $\begin{array}{l}\text { позитивних особистісних характеристик, здатних справляти } \\
\text { виховний вплив на інших людей. } \\
\text { Інакше кажучи, виховний потенціал дошкільного закладу } \\
\text { включає соціальний клімат, ресурси (іграшки та книги, ігри, } \\
\text { дидактичні матеріали, обладнання) і дошкільне середовище в } \\
\text { цілому, що відображає культурне різноманіття. Основним } \\
\text { «носієм» виховного потенціалу дошкільного закладу є педагог як } \\
\text { передавач поведінкових й культурних норм та цінностей. }\end{array}$ \\
\hline $\begin{array}{l}\text { 2. Реалізація та } \\
\text { розвиток виховного } \\
\text { потенціалу сім’'і, } \\
\text { партнерство } \\
\text { дошкільного закладу } \\
\text { та сім'ї }\end{array}$ & 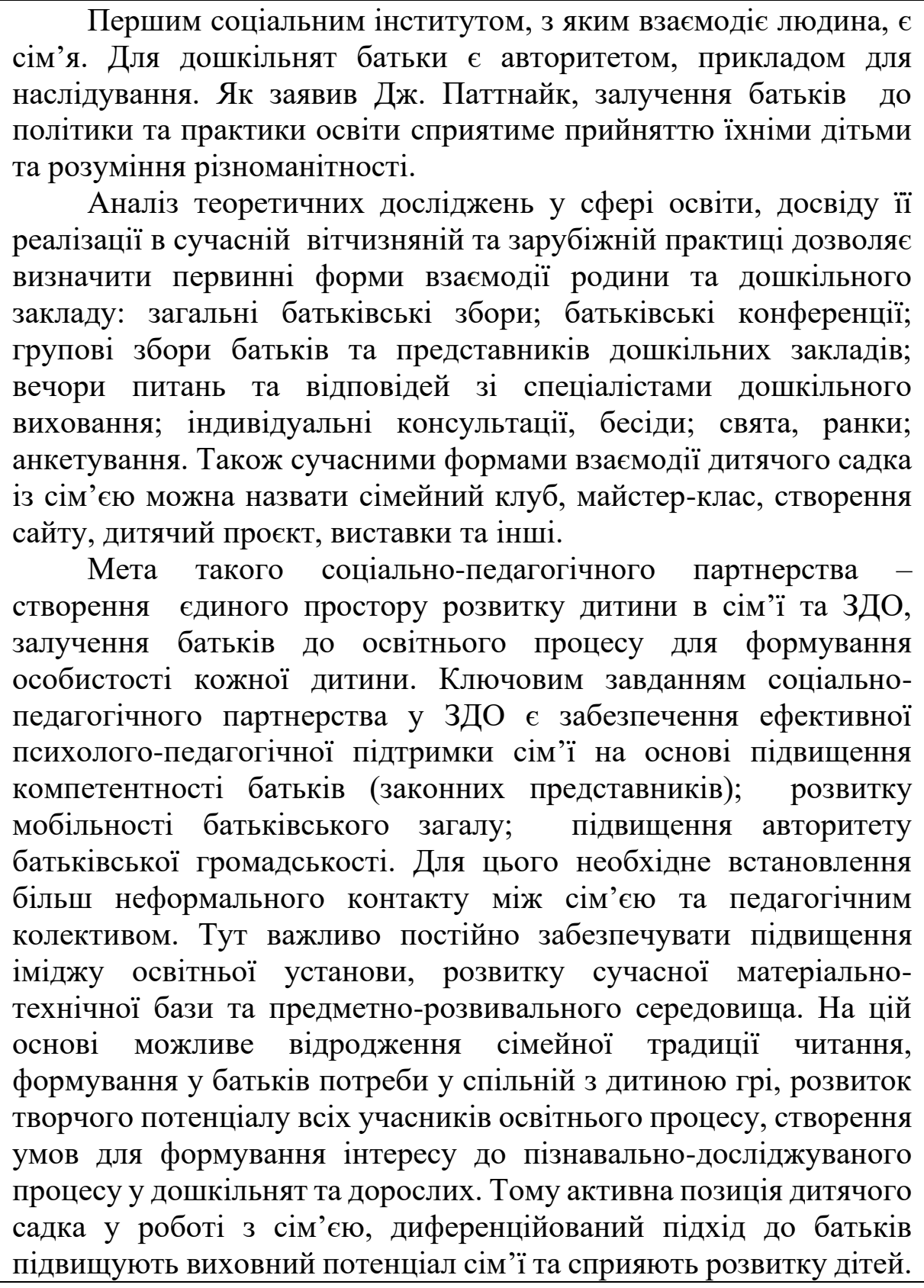 \\
\hline \multirow{2}{*}{\multicolumn{2}{|c|}{$\begin{array}{ccc}2 & \text { Продовження табл. } 1 \\
2 & \\
\end{array}$}} \\
\hline & \\
\hline $\begin{array}{c}\text { 3. Взаємодія } \\
\text { соціальних інститутів } \\
\text { і дошкільного закладу }\end{array}$ & $\begin{array}{l}\text { Навчальні та культурні заклади (середня школа, } \\
\text { етнокультурні центри, музеї тощо) мають чудовий потенціал для } \\
\text { реалізації освіти дошкільників. Таким чином, значну роль } \\
\text { відіграють музеї, що формують систему цінностей дітей та } \\
\text { залучають їх до історико-культурної спадщини. Не обов’язково } \\
\text { відводити маленьких дітей до нього. Сьогодні музеї пропонують } \\
\text { таку послугу, як «відвідувальна екскурсія», коли до дошкільного }\end{array}$ \\
\hline
\end{tabular}




\begin{tabular}{|c|c|}
\hline & $\begin{array}{l}\text { закладу «приїжджає» музей із захоплюючою освітньою } \\
\text { програмою. Ефективною практикою є створення міні-музеїв у } \\
\text { дошкільному закладі або організація «музею одного дня/тижня». } \\
\text { Ці музеї можуть відображати культурне різноманіття суспільства } \\
\text { та дошкільного закладу. В основі багатьох експозицій лежать саме } \\
\text { сімейні колекції. Прикладом може бути експозиція «Дерево роду», } \\
\text { що становить фотографії різних поколінь однієї сім'ї, сімейні } \\
\text { реліквії. Проведення у дитячому садку конкурсу міні-музеїв дає } \\
\text { додатковий змагальний стимул для прояву спільної творчості } \\
\text { педагогів, батьків та дітей. }\end{array}$ \\
\hline $\begin{array}{c}\text { 4. Включення } \\
\text { дошкільнят у } \\
\text { суспільно значущу } \\
\text { діяльність }\end{array}$ & 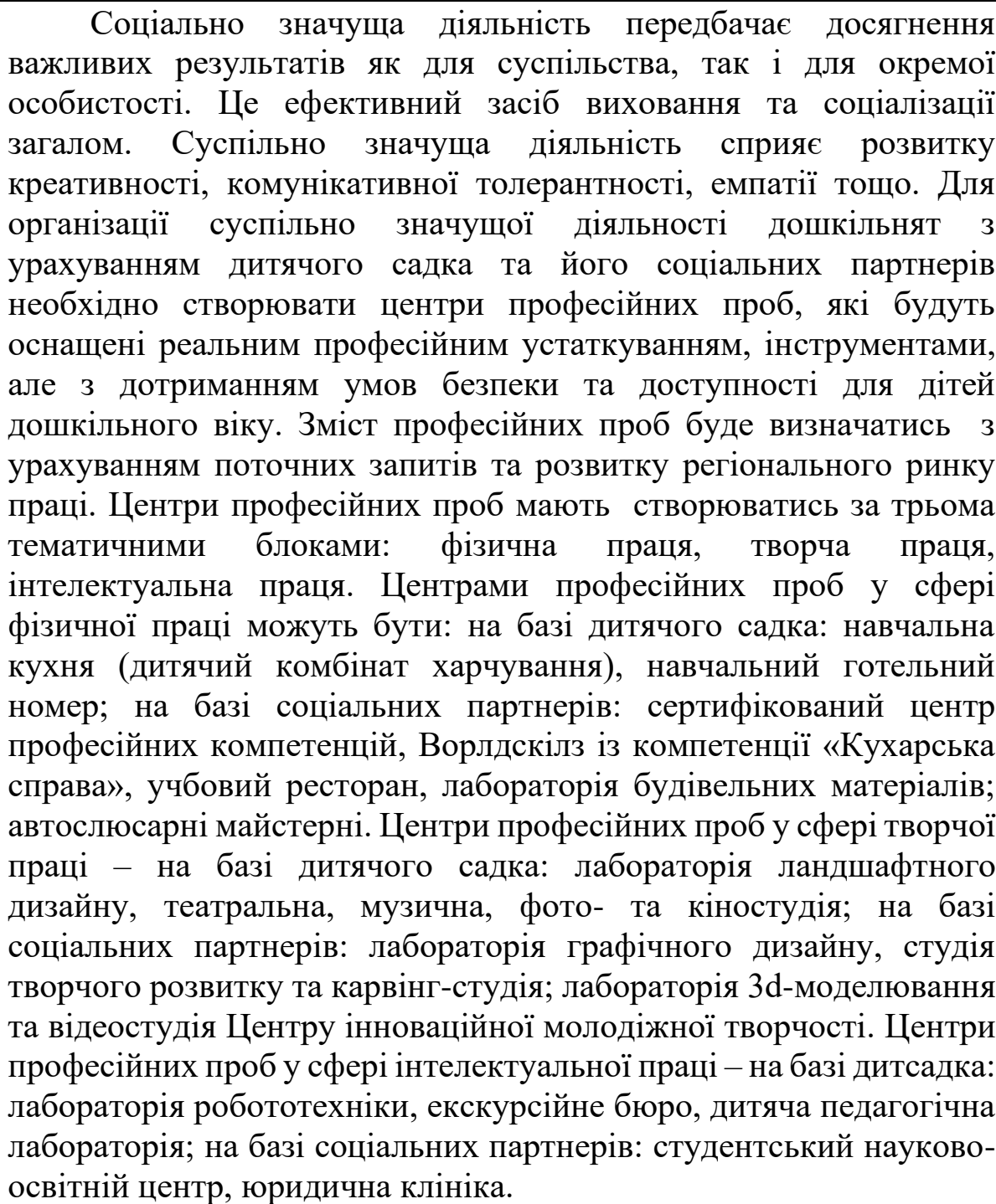 \\
\hline
\end{tabular}

У результаті проведеного аналізу науково-педагогічних джерел нами було виявлено проблеми, що ускладнюють організацію соціально-педагогічного партнерства:

1. На даний час слід зазначити недостатню взаємодію дошкільних освітніх організацій та батьків. Це пов'язано з тим, що батьки зайняті на роботі і не готові розумітися на тонкощах дошкільного навчання та виховання, що знижує ефективність розвитку соціально-педагогічного партнерства. 
2. Існує проблема одностороннього впливу, коли ініціатива йде не від самих батьків, а від педагогів. Одним із важливих аспектів соціального партнерства 3 сім'єю є встановлення взаємин у системі «педагог - батьки». Кожен із батьків має свою систему вимог до вихователя. Труднощі для педагога полягають у тому, що неможливо повністю виправдати очікування всіх батьків. Батьки довіряють вихователю найдорожче - свою дитину. Це повинні дуже добре розуміти вихователі і з цього погляду вибудовувати систему міжособистісних відносин.

3. Для певної частини батьків характерним $є$ прояв недовіри до того, що вихователь може вирішити їхні проблеми. Це свідчить про те, що відношення між вихователем та частиною батьків не досягають того рівня довірливості, без якого неможливо здійснити ефективний підхід до дитини та спільними зусиллями подолати труднощі їі виховання.

4. Відсутність програми освітніх цілей, яка спрямована на розвиток наступності дошкільної та початкової освіти дітей.

5. Недостатність педагогічних знань у деяких вихователів призводить до того, що їм складно побудувати взаємодію з дітьми. Отже, вихователю складно продумати захоплюючу освітню програму щодо підвищення якості дошкільної освіти.

6. У системі дошкільної освіти процес розширення громадської участі відбувається дуже повільно. Ця обставина пов'язана із закритістю системи дошкільної освіти від зовнішнього впливу, обмеженої здатності адекватно реагувати на запити сучасного суспільства, що призводить до зростання незадоволеності населення якістю та доступністю дошкільної освіти.

3 вищезазначеного можна дійти висновку, що 3 організації соціальнопедагогічного партнерства необхідно побудувати ефективну систему взаємодії дошкільної установи з об'єктами соціального оточення, які мають сприяти найбільш оптимальному розвитку творчих та інтелектуальних здібностей дітей.

Нині можна назвати такі напрями подальшого розвитку соціальнопедагогічного партнерства як чинника підвищення дошкільної освіти:

- підвищення рівня комунікативної компетенції педагогів із взаємодії 3 батьками для формування сімейних традицій;

- підвищення рівня психолого-педагогічних знань батьків;

- розвиток у педагогів та батьків здатності до позитивного діалогу;

- використання нових нетрадиційних форми та методів роботи з сім'єю, громадськими організаціями як чинник підвищення освіти дітей;

- педагогічна та психологічна освіта сім’ї через інформаційні технології;

- осучаснення змісту та технологій фахової підготовки майбутніх вихователів у контексті формування їх професійної та особистісної готовності до реалізації ідей педагогічного партнерства в професійній діяльності. 
Висновки. Таким чином, можна зробити висновок, що для підвищення якості дошкільної освіти необхідно побудувати соціально-педагогічне партнерство дошкільної освітньої організації, соціальних освітніх та культурних інститутів і сім'ї. Дані взаємини мають бути засновані на співробітництві, співдружності, взаємодопомозі, що призведе до підвищення якості освітніх послуг.

\section{ЛITEPATУРA:}

Алиева Т. И. Детский сад и семья: возможности социального партнерства. Дошкольное воспитание. 2017. № 12. С. 38-41.

Балалиева О.В. Социально-педагогическое партнерство как условие развития образовательной среды ДОУ: теоретическое обоснование. Дискуссия. 2012. № 6. С. 106-111.

Бузни В. А. Организация социально-педагогического партнерства как фактора повышения качества дошкольного образования. Проблемь современного педагогического образования. 2019. № 65-1.

Лісова Н. І. Механізми соціально-педагогічного партнерства в підручнику для керівника закладу освіти. Проблеми сучасного підручника: збірник тез Міжнародної наук.-практ. конфер. К.: Педагогічна думка, 2021. С.132-136.

Олійник Т. І. Педагогіка партнерства - як один із факторів ефективної взаємодії учасників освітнього процесу. Інтеграція як освітня стратегія модернізації дошкільної освіти: зб. наук. пр. Хмельницький: ХОІППО, 2019. С. 95-99.

Павлюк Л. Трансформація соціально-педагогічного партнерства в підготовці майбутніх учителів. Наукові записки БДПУ. 2020. Вип.1. С. 381-387.

Торохтий В. С. Социальная работа с семьей. Психологопедагогическое обеспечение: учебное пособие для академического бакалавриата. М.: Юрайт, 2019. 488 с.

Торохтий В. С., Савин Ю. В., Иванова О. А., Иванов В. С., Афанасьев В. В., Иванова Г. П., Сухова Е. И. Социальная педагогика: учебник и практикум. М.: Юрайт, 2018. 451 с.

Bakken L., Brown N., Downing B. Early childhood education: The long-term benefits. Journal of Research in Childhood Education. 2017. № 31(2). P. 255-269.

Logvinova O. K. Socio-pedagogical approach to multicultural education at preschool. Procedia Social and Behavioral Sciences. 2016. № 233. P. 206-210.

Pattnaik J. Multicultural Literacy Starts at Home: Supporting Parental Involvement in Multicultural Education. Childhood Education. 2003. № 80 (1). P. 18-24.

\section{REFERENCES:}

Alyeva, T. (2017), Detskiy sad i semya: vozmozhnosti sotsialnogo partnerstva [Kindergarten and family: opportunities for social partnership]. Doshkolnoe vospitanie [Preschool education]. № 12. P. 38-41 (in Russian).

Balalieva, O. (2012), Sotsialno-pedagogicheskoe partnerstvo kak uslovie razvitiya obrazovatelnoy sredyi DOU: teoreticheskoe obosnovanie [socio-pedagogical partnership as a condition for the development of the educational environment of a preschool educational institution: theoretical justification]. Diskussiya [Discussion]. № 6. P. 106-111 (in Russian).

Buzni, V. A. (2019). Organizatsiya sotsialno-pedagogicheskogo partnerstva kak faktora povyisheniya kachestva doshkolnogo obrazovaniya [Organization of social and pedagogical partnership as a factor in improving the quality of preschool education]. Problemyi sovremennogo pedagogicheskogo obrazovaniya [Problems of modern teacher education]. № 65-1 (in Russian).

Lisova, N. (2021). Mekhanizmy sotsialno-pedahohichnoho partnerstva v pidruchnyku dlia kerivnyka zakladu osvity [Mechanisms of social and pedagogical partnership in a handbook for a master 
to a mortgage of education]. Problemy suchasnoho pidruchnyka: zbirnyk tez Mizhnarodnoi nauk.-prakt. konfer [Problems of a day-to-day assistant: collection of theses of the International science.-pract. confer]. K.: Pedahohichna dumka. P.132-136 (in Ukrainian).

Oliinyk, T. (2019). Pedahohika partnerstva - yak odyn iz faktoriv efektyvnoi vzaiemodii uchasnykiv osvitnoho protsesu [Partnership pedagogy is one of the factors in the effective interaction of the participants in the educational process]. Intehratsiia yak osvitnia stratehiia modernizatsii doshkilnoi osvity: zb. nauk. pr [Integration as an illumination of the strategy of modernization of preschool education: zb.nauk.pr.]. Khmelnytskyi: KhOIPPO, P. $95-99$ (in Ukrainian).

Pavliuk, L. (2020). Transformatsiia sotsialno-pedahohichnoho partnerstva v pidhotovtsi maibutnikh uchyteliv [Transformation of social and pedagogical partnership in the preparation of maybutnih teachers]. Naukovi zapysky BDPU [Scientific notes of the BDPU]. Vyp.1. P. 381387 (in Ukrainian).

Torohtiy, V. S. (2019). Sotsialnaya rabota s semey. Psihologo-pedagogicheskoe obespechenie [Social work with the family. Psychological pedagogical support]. Moskva: Yurait. 488 p. (in Russian).

Torohtyi, V., Savin, Yu., Ivanova, O., Ivanov, V., Afanasev, V., Ivanova, G., Suhova, E. (2018). Sotsialnaya pedagogika [Social pedagogy]. Moskva: Yurait, 451p. (in Russian).

Bakken, L., Brown, N., Downing, B. (2017). Early childhood education: The long-term benefits. Journal of Research in Childhood Education№ 31(2). P. 255-269.

Logvinova, O. (2016). Socio-pedagogical approach to multicultural education at preschool. Procedia - Social and Behavioral Sciences. № 233. P. 206-210.

Pattnaik, J. (2003). Multicultural Literacy Starts at Home: Supporting Parental Involvement in Multicultural Education. Childhood Education. № 80 (1). P. 18-24.

Інформація про автора:
Апрслсва Ірина Вікторівна:
ORCID: http://orcid.org/0000-0002-3012-
7630; кандидат педагогічних наук, доцент,
доцент кафедра теорії та методики
дошкільної освіти, Комунальний заклад
«Харківська гуманітарно-педагогічна
академія» Харківської обласної ради,
провул. Руставелі, 7, м. Харків, Україна,
61001

e-mail: Apreleva555@gmail.com

\section{Information about the author:} Aprielieva Iryna Viktorovna: ORCID: http://orcid.org/0000-0002-30127630; Candidate of Pedagogical Sciences, Associate Professor, Associate Professor of the Department of theory and methods of preschool education, Municipal Establishment «Kharkiv Humanitarian Pedagogical Academy» of Kharkiv Regional Council, lane of Rustaveli, 7, Kharkiv, Ukraine, 61001

e-mail: Apreleva555@gmail.com

Цитуйте цю статтю як: Апрєлєва І. В. Соціально-педагогічне партнерство в освіті сутність, основні ідеї. Теорія та методика навчання та виховання. 2021. № 51. С. 7-17. DOI: $10.34142 / 23128046.2021 .51 .01$

Дата надходження статті до редакції: 14.09.2021

Стаття прийнята до друку: 29.09.2021 